\title{
Teaching Model design of Business English based on flipped classroom case study
}

\author{
Ling Zhang ${ }^{1, a}$ \\ ${ }^{1}$ Beijing Wuzi University, Beijing, China \\ arene_zhangling@hotmail.com
}

Keywords: Flipped classroom; Business English.

\begin{abstract}
Flipped classroom symbolizes the achievement of education innovation by applying information technology to education. Under flipped classroom teaching mode, students learn the knowledge before class via information technology while the internalization process will be completed in class under teacher's guide. The teaching principle may provide a new attempt in tackling issues occurred in Business English teaching process. This essay has studied the successful flipped classroom cases abroad, based on the results, a teaching mode in Business English flipped classroom which accords with China's situations has been created and students' attitudes towards flipped classroom teaching mode have been researched through both quantitative and qualitative experimental methods. According to the results, the new mode - flipped classroom teaching mode has been highly appraised by students.
\end{abstract}

\section{The Teaching Dilemma of Business English}

With the booming birth of new technologies, the combination of information technology and courses has been increasingly strong. Being the symbols of the new generation of information technology, mobile internet, cloud computing and the Internet of Things have promoted the revolution of educational system and provided convenient and fast technical support.

Being one of the compulsory courses for business English major, the course of Business English has a lot of basic concepts covering a wide range of knowledge and full of theoretical definition, students not only need to master the basic concepts as well as basic theories, they also need to pay attention to the application of theoretical knowledge in business environment and build up their ability of self-learning. The teaching quality of this course directly influences how deep students can master the basic theories and how well they can use the language and may even influence the employment issue of graduates. The following problems can be found in traditional Business English teaching process: too much content, high capacity, low resource utilization rate, frozen pre-class preparation, few class hours, poor study results, little communication between students and teachers as well as students themselves, not enough discussion time for key questions in class, few practical opportunities for main business scenarios etc. To tackle the above issues, a mixing teaching method of combining internet education and face-to-face education can be adopted in such an age of internet and education informatization development. This essay has discussed the application of flipped classroom to Business English courses. The birth of flipped classroom has provided a new teaching method to Business English.

\section{Definition and advantages of Flipped Classroom}

The origin of Flipped Classroom. Flipped Classroom originated in WoodlandPark High School in Colorado, USA. In the spring of 2007, the two teachers in chemistry, Jon Bergmann and Aaron Sams (2013) started to use screen recording software to record their PPT and their teaching voices, and then they uploaded the video to internet to help those absent students with their study. Afterwards, the two teachers decided to have their students watch the teaching videos at home and finish their homework in class and they could give instructions to those who had difficulties in studying. The teaching mode was widely appraised by students. To help more teachers understand and accept the 
idea and method of flipped classroom, they held an open-day flipped classroom in Woodland Park High School on Jan 30th, 2012 so that more teaching staff were able to observe how flipped classroom operated and how students were studying, which had helped to spread the mode of flipped classroom. What's more, the promotion of flipped classroom also benefited from OER. Since MIT has initiated OCW, the emergence of a number of high quality educational resources such as Yale open class, Khan Academy videos, TED ED, etc., has provided resource support for the development of flipped classroom and its education.

The features of flipped classroom. The traditional teaching process includes two phases: knowledge pass and knowledge internalization. Knowledge pass phase is completed by teaching from teachers in class while knowledge internalization phase is realized in the homework, operation or practice sessions after class. In flipped classroom, the mode has been reversed: the knowledge pass phase is completed after class with the help of information technology while the knowledge internalization phase is achieved in class through the teachers' help and mutual assistance from classmates, thus a flipped classroom is formed. Due to the reversal of education process, each phase in class has changed accordingly. The comparison of different factors between traditional classroom and flipped classroom is listed in Table 1.

Table 1. Comparison table of different factors between traditional classroom and flipped classroom

\begin{tabular}{|c|c|c|c|c|c|c|}
\hline & $\begin{array}{c}\text { Teaching } \\
\text { mode }\end{array}$ & $\begin{array}{c}\text { Content in } \\
\text { class }\end{array}$ & $\begin{array}{c}\text { Technology } \\
\text { application }\end{array}$ & Tests & Teacher & Students \\
\hline $\begin{array}{c}\text { Traditional } \\
\text { classroom }\end{array}$ & $\begin{array}{c}\text { In-class } \\
\text { instruction } \\
\text { and } \\
\text { after-class } \\
\text { homework }\end{array}$ & $\begin{array}{c}\text { Knowledge } \\
\text { explanation } \\
\text { and pass }\end{array}$ & $\begin{array}{c}\text { Content } \\
\text { display }\end{array}$ & $\begin{array}{c}\text { Tradition } \\
\text { al paper } \\
\text { tests }\end{array}$ & $\begin{array}{c}\text { Knowledge } \\
\text { passer, class } \\
\text { administrator }\end{array}$ & $\begin{array}{c}\text { Passive } \\
\text { receiver }\end{array}$ \\
\hline $\begin{array}{c}\text { Flipped } \\
\text { classroom }\end{array}$ & $\begin{array}{c}\text { Pre-class } \\
\text { study and } \\
\text { in-class } \\
\text { exploration }\end{array}$ & Problem & $\begin{array}{l}\text { Self-study, } \\
\text { explommution } \\
\text { ion, } \\
\text { cooperation, } \\
\text { discussion }\end{array}$ & $\begin{array}{c}\text { Manifold } \\
\text { angles } \\
\text { and } \\
\text { methods }\end{array}$ & $\begin{array}{c}\text { Instructor and } \\
\text { promoter in } \\
\text { studying }\end{array}$ & $\begin{array}{c}\text { Initiative } \\
\text { researchers }\end{array}$ \\
\hline
\end{tabular}

\section{The Flipped Classroom Mode in Business English}

Analysis of how students study. Most students in our school are at the age of 18 - 22, they are becoming more mature; they are able to learn by themselves with strong self-learning ability and problem recognizing ability; they dare to doubt and discuss problems with teachers on the same level; they also have innovation spirit and practice awareness; most of them have strong language organization ability and presentation skills, being able to express their view and experience towards studying to others.

Design of teaching strategy. With constructivism being the guiding ideology, students are usually the center of learning process, while teachers give instructions by such learning strategies as collaborative learning, discovery learning, etc. in the teaching process in flipped classroom. By preparing well-designed teaching materials in advance, teachers have altered the in-class contents to after-class ones for students to learn by themselves. The classroom is no longer a main spot for teachers to teach, instead, it has become a place for students to cooperate, discuss and explore the knowledge as well as a place for teachers to communicate with students and offer them both studying guide and feedback, which means that teachers are not solely a knowledge passer any more, but have become the main promoters and instructors for students. Teachers have become the platform for students to conveniently gain, utilize and handle the learning resources and learning information.

To form the flipped classroom mode in Business English. According to teaching features and teaching ideology under the scheme of theoretical guide of constructivism learning, the writer has 
formed a flipped classroom teaching structure appropriate for Business English teaching process through his/her long-term observation in class. The details are shown in Fig.1.

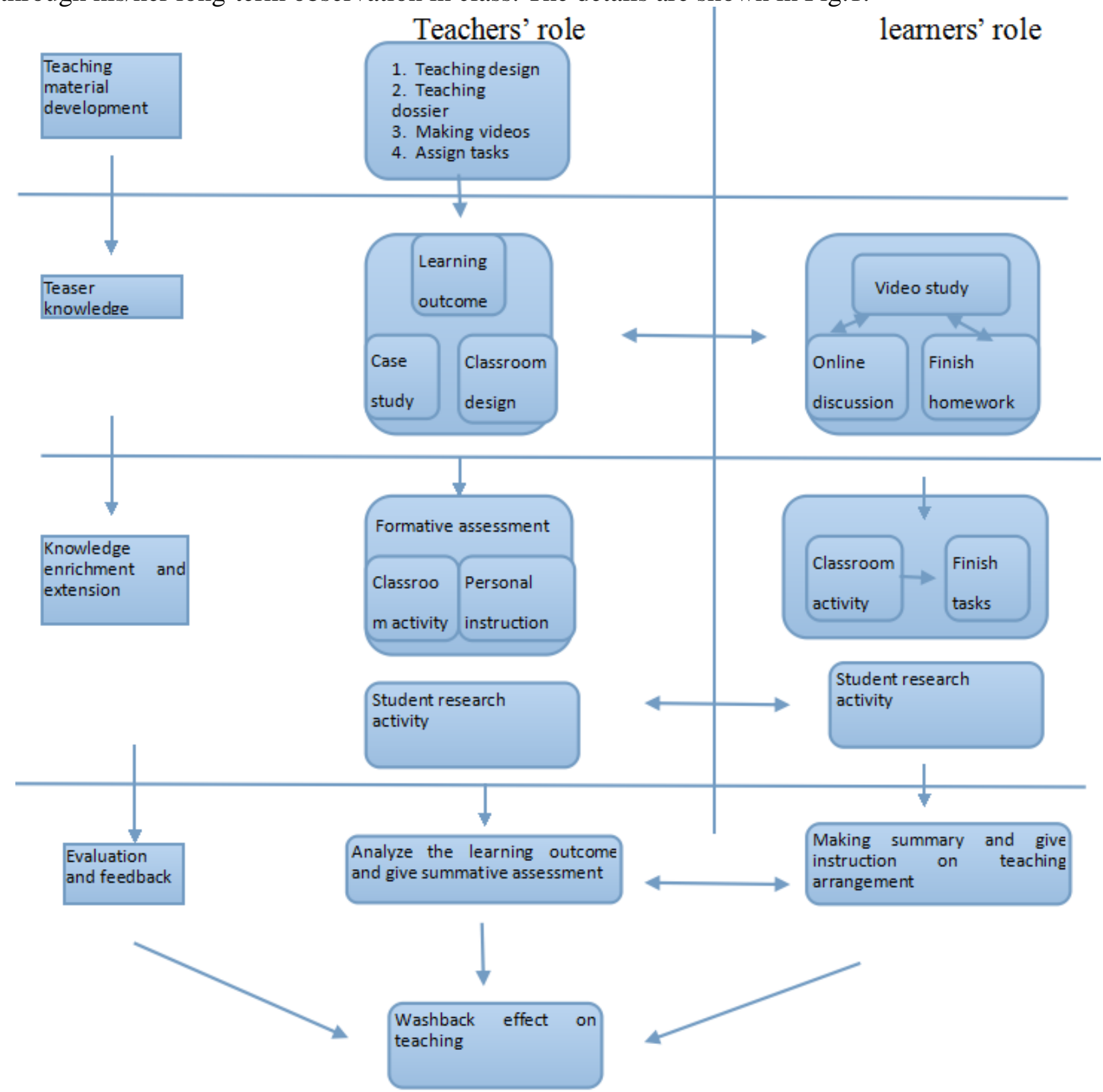

Fig.1 has shown that with the support of information technology, the teaching mode of flipped classroom is able to connect the pre-class knowledge pass, in-class knowledge application and after-class knowledge supplement together effectively, thus creating an environment for students to learn by themselves. The teaching mode of flipped classroom is generally the same as that of other flipped classrooms, namely, pre-class preparation, students learn by themselves, in-class practice, feedbacks and evaluation.

Prepare teaching videos before class. In a flipped classroom, the knowledge pass phase is completed by the videos provided by teachers. Based on the analysis of teaching content and features of students, teachers will set the teaching goals and refine the content into relatively tiny, integrated and relevant parts, and then create videos via screen recording software, i.e. Camtasia Studio 6.0. The video should accord with the teaching goals and content. When creating the videos, students' feature should be taken into great consideration to suit their learning methods and habbits.

Students learn by themselves before class. This phase is key to flipped classroom because the smooth running of flipped classroom depends on whether the self-learning phase is successful or not. Students watch the videos provided by teachers themselves and should record what they have obtained as well as their questions. What's more, students need to complete the pre-class exercise 
specially prepared by teachers so that the content will be consolidated and their questions can be discovered. In this process, students can use manifold social tools to cooperate with their companions to learn.

In-class activity. In the flipped classroom teaching mode, in-class activity is the internalization process of knowledge. Teachers use the slot in classroom to carry on high quality and effective in-class study to answer students' questions and organize them to carry on all kinds of activities such as collaborative research, group discussion, knowledge contest, scene design practice, finish homework and independent problem solving etc. so that students can gain self-learning ability, team work spirit as well as group collaboration. Those who have difficulty in studying can use the resources provided by teachers both pre-class and after-class to supplement themselves.

Feedbacks and evaluation. When each unit has been completed, how well the students have mastered the knowledge will be evaluated through homework and exams; by feedbacks and evaluation, problems can be found in the process so that the teaching strategy can be adjusted and modified, i.e. give group tutoring to students or personalized instruction, thus the application effect of flipped classroom can be improved.

\section{Current Results from the Experiment}

To have overall attitudes from students towards the flipped classroom teaching mode, we have separately done both qualitative and quantitative data research on students. To keep the research objective, the data are collected anonymously. Qualitative data were collected in likert 5-level scale (i.e. 1 =very dissatisfied; 2 =dissatisfied; $3=$ ordinary; 4=satisfied; 5=very satisfied), the attitudes towards the flipped classroom teaching mode from 500 students who took part in the experiment have been collected. The two dimensions are teaching design from teachers and learning by students themselves. The qualitative data have been collected in the form of structural written interview, i.e. 50 students were chosen randomly and their feedback scripts were coded and categorized to be the base of qualitative discussion.

The results of the study are as follows:

\section{Qualitative data results}

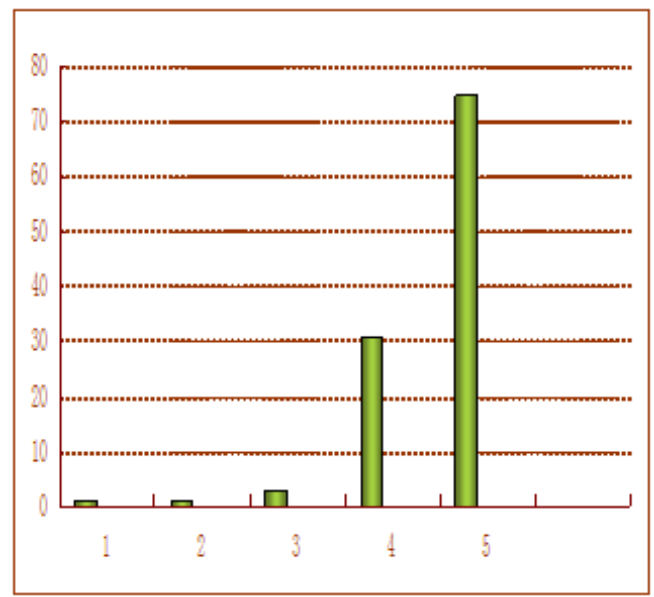

Fig.2. Learners' satisfaction on Flipped classroom 


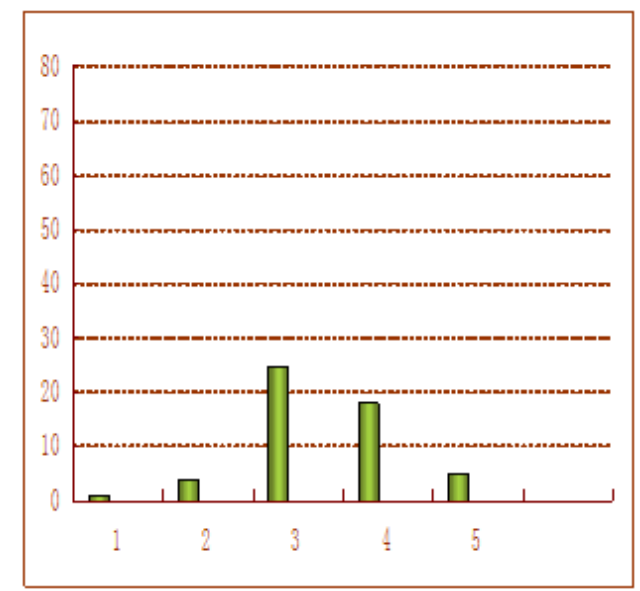

Fig.3. Learners' satisfaction on Traditional classroom

Students' qualitative feedbacks towards flipped classroom study mode in two dimensions are shown in Fig.2 and Fig.3, the satisfaction from the students on teaching design of flipped classroom has the highest rank, reaching $99.7 \%$ (Mean $=4.67, \mathrm{SD}=0.474$ ). Meanwhile, over $42.9 \%$ of the students have found themselves satisfied on the study through flipped classroom (Mean $=3.37, \mathrm{SD}=$ 0.859). To further compare the different effects of two teaching dimensions (teaching design of teachers vs. self-learning) in both traditional classroom and flipped classroom, we use SPSS 17.0 to analyze the likert results of the students via Double factor variance analysis. The results have shown that the main effect of the study mode is remarkable $(F=26.13, P=0.000)$; the main effect of teaching dimension is remarkable $(\mathrm{F}=111.07, \mathrm{P}=0.000)$; the interaction effect between them is remarkable $(\mathrm{F}=17.00, \mathrm{P}=0.000)$. Further tests have shown that under a flipped classroom mode, students feel more satisfied with teachers' teaching design than their own self-learning $(\mathrm{T}=11.13, \mathrm{P}=$ 0.000). The results have indicated that although students think they should improve their self-learning, they have also approved the teaching mode in flipped classroom. From the dimension of teachers' teaching design, students feel less satisfied with in-class teaching design than in-class teaching $(\mathrm{T}=$ -8.19, $\mathrm{P}=0.000$ ). This result shows that the teaching design in the video for flipped classroom need further improvement, students may also need to adapt themselves to online learning. The following is the discussion on quantitative interview.

Quantitative results discussion. High evaluation from the students towards flipped classroom can be concluded to three aspects: firstly, this mode can make students gain a lot of vocabulary and terms. Students say that the new mode has surpassed the traditional business English knowledge learning and made them "understand more about terms and exchange many opinions", "the in-class discussion can help them practice listening and oral English, the business scenarios are abundant and interesting". These results have accorded with our teaching goal set to flipped classroom. Secondly, this new mode has strengthened students' learning motivation and fulfilled their affection need. Students say that the flipped classroom "has more interaction with teachers, the lively class has made me want to learn more", "has made me understand the importance of pre-class preparation and has encouraged me to make presentation in class". Finally, some students say that after they rethink themselves, they found that "I am not proactive enough to make presentation in class and weaken the study results; insufficient preparation to group activities has made it ordinary written homework and will improve myself next time". This indicates that flipped classroom can facilitate student's reflective learning. Meanwhile, students may have reflection towards the possible flaw in flipped classroom. Some students say that "they don't gain much knowledge in class, the key is pre-class or after-class". This has reminded us of the combination between in-class teaching and online self-learning should be carried on at the same time, neither can be neglected so that the advantages from both sides can supplement each other and the input as well as output of language knowledge skills can be improved accordingly. 


\section{Conclusion}

This study has done a completely new teaching design on Business English course through flipped classroom teaching mode and done comprehensive research on students' attitudes towards the mode via both qualitative and quantitative experimental methods. The results have shown that under the new mode, flipped classroom has been highly appraised by students. From the students' perspective, although some students find themselves not suitable to the self-learning ability as required in class, they still think that the traditional text teaching in Business English course should be abandoned, flipped is inevitable. For teachers, under the new mode, they will not be "laid off", but "shift" is a must, otherwise the class of Business English may fail to embody the course goal as "build up students ability to use business English in practice", making the teaching of Business English something formalistic. In the end, it is necessary to point out that the participation in the process of flipped classroom teaching design is both the professional development process for teachers (Jiehui HU, 2014:90-92) and the trend of foreign language teaching, which need the involvement of both teachers and students to progress further.

\section{Acknowledgements}

This work was supported by the project "Beijing Higher Education Young Elite Teacher Project". The project number is "yetp1534".

\section{References}

[1] Jonathan Bergmann \& Aaron Sams, Flip your classroom: Reach Every Student in Every Class Every Day [M] . ISTE ASCD. 2012.

[2] Zhang,Y.J, Flipped Classroom Revolution [J], China IT Education, 2012, (10):118-121.

[3] Clintondale High School [EB/OL ] . http: / /www. flippedhighschool. com/ourstory . php, 2012-04-10

[4] Bergman, J., \& Sams, A. (2011). How the flipped classroom was born. The Daily Riff. Retrieved from

http://www.thedailyriff.com/articles/how-the-flipped-classroom-is-radically-transforming-learn ing-536.php

[5] Frydenberg, Mark (2012). "Flipping Excel." Proceedings of the Information Systems Educators Conference, Volume 29, Number 1914, 1-11.

[6] Starzee, Bernadette (2012). "Flipped Classroom Model Leaps to Long Island". Long Island http://libn.com/2012/04/04/flipped-classroom-model-leaps-to-long-island/ Business News, April 4,

[7] Steed, Anthony (2012). "The Flipped Classroom." Teaching Business \& Economics, Autumn, 9-11. 